\title{
Environmental Impact for Applications of Neem Cake Coated Urea and Nano Iron Foliar on Rationalization of Chemical Nitrogen Fertilizers and Wheat CHECKED Yield \\ Shreen S. Ahmed ${ }^{1}$ and A. H. Fahmy ${ }^{2}$ \\ ${ }^{1}$ Soils, Water and Environment Research Institute, Agricultural Research Center, Giza, Egypt \\ ${ }^{2}$ Agriculture Genetic Engineering Research Institute, Agricultural Research Center, Giza, Egypt
}

\begin{abstract}
Slow release fertilizer has become a new trend for saving chemical fertilizer consumption and to minimize environmental pollution. This study was aimed to use neem cake as a natural material for coating urea for improving fertilizer efficiency and reduce $\mathrm{N}$-losses. Also to investigate the application of neem cake coated urea with or without foliar nano iron on wheat productivity. Neem cake coated urea and nano iron were prepared. Two experiments (incubation and field) were carried out. Incubation experiment was conducted using soil samples to study the efficiency of the use neem cake coated urea on $\mathrm{NH}^{+}$ release under conditions of saturated and field capacity for nine weeks. A field experiments was carried out to study the effect of neem coated urea with or without nano iron as foliar spray on $\mathrm{N}$-use efficiency, wheat yield, components and nitrate leaching. The results of incubation experiment showed that, the release of $\mathrm{NH}_{4}^{+}$was the highest under saturated conditions as compared with field capacity. The release of $\mathrm{NH}_{4}{ }^{+}$from neem coated urea was slow for a long period of time compared to uncoated urea. The data of the field experiment showed that the application of neem coated urea fertilizers led to a lower concentration of nitrate in drainage water. A highest increase in the grain yield of wheat was recorded by application of neem coated urea fertilizers with foliar nano iron compared to uncoated urea as a control. Results illustrated that controlled released urea fertilizer improved yield by $24 \%$ and enhanced $\mathrm{N}$ uptake up to $77 \%$ as compared to uncoated urea as control treatment. Applied of neem coated urea and nano iron foliar has increased nitrogen uptake and recovery efficiency of wheat. From the results obtained, it could be concluded that, the possibility of using neem coated urea as well as foliar spraying with nano iron for rationalize the use of nitrogen chemical fertilizers, thereby reducing the pollution as well as reducing the costs of agricultural production.
\end{abstract}

Keywords: Neem coated urea, nano iron, nitrogen use efficiency, nitrate leaching, wheat, and yield.

\section{INTRODUCTION}

Poor nutrient utilization and nitrogen losses from urea applications have been reported for many years (Khalil et al., 2009). The $\mathrm{N}$ losses from applied urea were estimated at 30 to $60 \%$ in tropical soil due to different losses i.e., volatilization, leaching ...etc, reducing the use efficiency of applied fertilizers (Ramesh et al., 2010). This reduces the productivity and increases the cost of cultivation besides polluting the environment (Khalil et al., 2003; Zhang et al., 2010).

Recently, the use of slow release fertilizers is a new trend to save fertilizer consumption and to minimize environmental pollution (Jarosiewicz and Tomaszewska 2003 and $\mathrm{Li}$ et al., 2016). Slow release fertilizers are made to release their nutrient contents gradually and to coincide with the nutrient requirement of a plant (Tyliszczak et al. 2009). These fertilizers can be physically prepared by coating granules of conventional fertilizers with various materials that reduce their dissolution rate (Tomaszewska et al. 2002). The release and dissolution rates of water-soluble fertilizers depend on the coating materials. The membrane materials developed can be divided into two main varieties, inorganic mineral and organic polymer (Zou et al. 2009). In this context, the controlled release technology by coating urea with different materials such as phosphogypsum, sulphur, resin polymers, Dicyclo pentadiene (DCPD), pine tree Kraft lignin and neem using different techniques of rotating drum, fluidized bed and spouted bed to increase the efficiency of urea fertilizer has been investigated (Susherman and Anggoro, 2011).

Neem cake has an adequate quantity of NPK in organic form for plant growth. Being a totally botanical product it contains $100 \%$ natural NPK content and other essential micro nutrients as $\mathrm{N}(2-5 \%), \mathrm{P}(0.5-1.0 \%), \mathrm{K}$ (1-2\%), Ca (0.5-3.0\%), Mg (0.3-1.0\%), S (0.2-3.0\%), $\mathrm{Zn}$ (15 - 60 ppm), Cu (4 - 20 ppm), Fe (500 -1200 ppm), Mn (20 - 60 ppm). It is rich in both sulphur compounds and bitter limonoids. According to research calculations, neem cake seems to make soil more fertile due to an ingredient that blocks soil bacteria from converting nitrogenous compounds into nitrogen gas. It is a nitrification inhibitor and prolongs the availability of nitrogen to both short duration and long duration crops (Schmutterer, 2002).

Neem and its parts are being used to manufacture urea coating agent to improve and maintain the fertility of soil. Use of neem urea coating agent helps to retard the activity and growth of the bacteria responsible for denitrification (Susherman and Anggoro, 2011). It prevents the loss of urea in soil. Urea coating is generally available either in liquid form or powder form.

In plant, micronutrients play an important role in the production and productivity. Among micronutrients, Iron is a cofactor for approximately 140 enzymes that catalyze unique biochemical reactions (Brittenham, 1994). Iron is required at several steps in the biosynthetic pathways (Miller et al., 1995). Singh and Dayal, (1992) concluded that spraying iron would cause a $38-42 \%$ increase in the peanut yield in alkaline soils. Zareie et al., (2011) with study effect of nitrogen and iron fertilizers on seed yield and yield components of safflower genotypes was reported that, use of foliar spraying of iron fertilizer had significant effect on seeds per head and seed yield of safflower genotypes. The present investigation was conducted to find out how far 
natural material coated urea products were able to save fertilizer consumption and to minimize environmental pollution and to study the effect of foliar spraying of nano iron on wheat yield and yield components.

\section{MATERIALS AND METHODS}

This Work was divided into three steps: 1) Preparation of neem cake coated urea and Nano iron. 2) Experimental of soil incubation was conducted to study the efficiency of the use neem cake coated on
$\mathrm{NH}_{4}{ }^{+}$-Release. 3) Field experiment was carried out to study the effect of neem cake coated urea and foliar application of nano iron on $\mathrm{N}$-use efficiency, wheat yield, components and nitrate leaching.

\section{Synthesis of neem cake coated urea}

A solution containing $5 \mathrm{~g}$ of wax in $10 \mathrm{ml}$ of hexan was prepared and mixed with $1 \mathrm{~kg}$ urea and kept aside for 30 minutes for proper soaking of urea; then 50 $\mathrm{g}$ of finely powdered and sieved neem cake was mixed thoroughly with urea for their uniform coating Fig. (A).
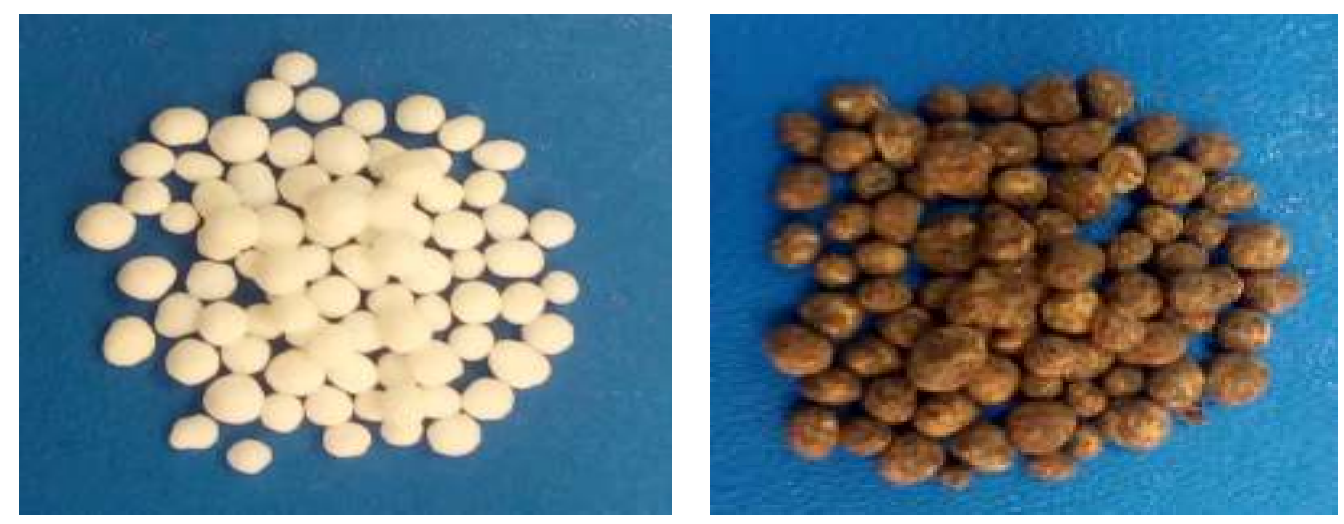

Urea before coated with Neem cake

Urea after coated with Neem cake

Fig. A. Urea before and after coated with Neem cake

\section{Synthesis of Nano iron:}

Three steps preparation scheme for iron nanoparticles according to Sun et al., (2006) starts with a solution of $\mathrm{NaBH}_{4}(0.8 \mathrm{M})$ in deionized water was prepared as a reducing agent and mixing with $\mathrm{FeCl}_{3} \cdot 6 \mathrm{H}_{2} \mathrm{O}(0.2 \mathrm{M})$ for $5 \mathrm{~min}$ at $25^{\circ} \mathrm{C}$. Next, solution was filtrated and washed the Precipitate with deionize water for removal the excessive amount borohydrate. Nano iron particles were dried under $\mathrm{N}_{2}$ gas and were saved from the oxidation by adding a thin layer of ethanol.

Incubation of soil samples with coated urea:

This experiment was conducted to study the controlling release technology by coating urea with neem coated to reduce nitrogen fertilizer losses and reduce the environmental pollution. One $\mathrm{kg}$ of soil samples that collected from the farm of Agriculture Research Centre was weighted. Urea fertilizer in this experiment was applied at four treatments, (1) 100\% urea (U) as a control, (2) Neem cake coated 100\% urea (NCCU100), (3) 80\% Urea, and (4) Neem cake coated $80 \%$ urea (NCCU80). Each treatment from urea fertilizer was added to be the final concentration of the urea fertilizer was $1000 \mathrm{mg}$ urea/ $\mathrm{kg}$. The soil and fertilizer was mixed well. $20 \mathrm{~g}$ of soil samples were weighted and transferred to separate foil cups and moisture content was added to bring the soil samples to field capacity (FC) and saturated (ST), respectively. At regular intervals, the cups were weighted and the moisture content was maintained constant at FC and ST. The cups were incubated at the room temperature (20- $25^{\circ} \mathrm{C}$ ) for 9 weeks. Samples of soil were taken after 1 , $2,3,4,5,6,7,8$ and 9 weeks of incubation for determination the release of $\mathrm{NH}_{4}^{+}$.

\section{Field experiment:}

This experiment was carried out to evaluate the use of neem cake coated urea and foliar nano iron to improve the efficiency of nitrogen fertilizer and increase wheat yield. In winter season (2016/2017) wheat grains (Triticum aestivum L.) cultivar Sakha 93 were grown the farm of Agricultural Genetic Engineering Research Institute, Agriculture Research Centre - Giza Governorate, Egypt. The experiment was carried out in a complete randomized blocks with three repetitions with plot area $1.5 \mathrm{~m}^{2}(1 \times 1.5 \mathrm{~m})$. The treatments were eight treatments; (1) $100 \%$ urea (U) as a control, (2) $100 \%$ urea $+\mathrm{Fe},(\mathrm{U} 100+\mathrm{Fe},(3)$ Neem cake coated $100 \%$ Urea (NCCU100), (4) Neem cake coated 100\% urea + Fe (NCCU100 + Fe), (5) 80\% urea (U 80), (6) $80 \%$ urea $+\mathrm{Fe}(\mathrm{U} 80+\mathrm{Fe}),(7)$ Neem cake coated $80 \%$ urea (NCCU80), (8) Neem cake coated $80 \%$ urea $+\mathrm{Fe}$ $(\mathrm{NCCU} 80+\mathrm{Fe})$

Some characteristics of the studied soil before sowing are presented in Table (1). Wheat was fertilized with $\mathrm{P}$ and $\mathrm{K}$ according to the recommended rates (200 $\mathrm{kg} \mathrm{P}_{2} \mathrm{O}_{5}$ fed $^{-1}$ and $24 \mathrm{Kg} \mathrm{K}_{2} \mathrm{O}$ fed $^{-1}$ ). Nano iron was applied at a rate of $100 \mathrm{ppm}$ as foliar spray. Three times of foliar application was carried out, the first time was after 90 days (booting stage) and 105 days (heading stage) and 120 days (milking stage). 


\section{Analytical methods}

Some characteristics of the studied soil were analysed according to Page et al., (1982). Soluble and available ammonium and nitrate were determined according to Chapman and Pratt., (1961) using Micro Kiedahel.

Table 1. Some physical and chemical properties of the studied soil

\begin{tabular}{lc}
\hline Physical & Value \\
\hline Coarse sand\% & 6.1 \\
Fine sand\% & 19.9 \\
Silt\% & 38.5 \\
Clay\% & 35.5 \\
Texture class & loamy clay \\
Chemical properties & \\
pH (1: 2.5, soil suspension) & 7.72 \\
Organic matter (\%) & 1.19 \\
ECe dS m ${ }^{-1}$, soil paste extract & 1.74 \\
Soluble cations (meq/L) & \\
$\mathrm{Ca}^{++}$ & 8.2 \\
$\mathrm{Mg}^{++}$ & 4.1 \\
$\mathrm{Na}^{+}$ & 3.5 \\
$\mathrm{~K}^{+}$ & 1.6 \\
$\mathrm{Soluble}^{+}$anions (meq/L) & \\
$\mathrm{CO}^{-}$ & - \\
$\mathrm{HCO}^{-}$ & 5.1 \\
$\mathrm{Cl}^{-}$ & 5.3 \\
$\mathrm{SO}^{=}$ & 7.0 \\
\hline
\end{tabular}

At the harvest all plants were harvested and collected per plot then yield per feddan was calculated. Phosphorus content in plant sample, was estimated by vana domolybdate yellow method spectrophotometrically and K by flame photometer (Jackson, 1973). Total nitrogen was estimated by micro-Kjeldahl method according to (AOAC.,1990). Total carbohydrate was extracted according to (Smith, et al. 1964) and determined using spectrophotometer according to (Murphy, 1958). Protein was calculated by multiplying the values of total nitrogen in 5.75. All data were statistically analyzed using MSTATC computer program according to procedures outlined by Freed and Scott, (1986).

Calculate Nitrogen Use Efficiency:

Nitrogen Use Efficiency (NUE) $(\%)=[(\mathrm{N}$ uptake of $\mathrm{N}$ treatment $-\mathrm{N}$ uptake of $\mathrm{N}$ deficiency treatment) / $\mathrm{N}$ unit application] $\times 100$.

Agronomic $\mathrm{N}$ efficiency $(\mathrm{kg} / \mathrm{kg})=($ yield $\mathrm{N}$ treatment yield $\mathrm{N}$ deficiency treatment)/ $\mathrm{N}$ unit applied.

\section{Economic Evaluation:}

The yield components were calculated and economical analysis performed using the following equation out lined by FAO (2000).

1) Total return $=$ yield $\times$ price $($ grain + straw $)$

2) Net return $(\mathrm{NR})=$ Total return - Total cost of production

3) Investment factor (IF) = Net return (NR) / Total cost of production

\section{RESULTS AND DISCUSSIONS}

\section{Incubation experiment:}

$\mathrm{NH}_{4}{ }^{+}-\mathrm{N}$ release:

Neem coated urea fertilizers were applied to soil to study the release of $\mathrm{NH}_{4}{ }^{+}-\mathrm{N}$ at different times of incubation under saturated percentage and field capacity compared to Urea as a control. The results showed that, the release of $\mathrm{NH}_{4}^{+}-\mathrm{N}$ was the highest under saturated conditions than field capacity (Figs. 1 and 2). Data showed that the uncoated urea has rapid hydrolysis; releasing the highest $\mathrm{NH}_{4}{ }^{+}$at the first week. The values of ammonia reached 415 and $388 \mathrm{ppm}$ for saturated and field capacity, respectively. Data also showed a decrease of $\mathrm{NH}_{4}^{+}$release with increase the time of incubation reaching to 15 and $16 \mathrm{ppm}$ at nine week for saturated and field capacity, respectively. Regarding the neem coated urea, the results revealed that the value of releasing $\mathrm{NH}_{4}{ }^{+}$at the first week was reached 286 and $210 \mathrm{ppm}$ for saturated and field capacity compared to control. Data also showed an increase in the release of ammonia with increase the time of incubation. The highest values of $\mathrm{NH}_{4}{ }^{+}-\mathrm{N}$ reached to 330 and $286 \mathrm{ppm}$ for saturated and field capacity, respectively. Generally, the release of $\mathrm{NH}_{4}^{+}$has increased rapidly in uncoated urea compared to coated urea. The slow release of $\mathrm{NH}_{4}{ }^{+}$-N using neem coated urea was due to the resistant coating provided by the neem cake to the entry of water into the urea granule, and also might be due to the inhibition of urease activity in the soil as a result to the action of neem cake (Singh et al., 1996; Purakayastha et al., 1997). Neem coated urea also released $\mathrm{NH}_{4}{ }^{+}-\mathrm{N}$ for a longer period without conversion to $\mathrm{NO}_{3}^{-}$because of nitrification inhibition phenomenon due to presence of neem cake coating.

\section{Field experiment: \\ Nitrate leaching:}

Sampling of water was collected from through the pezometer after soil irrigation (six times irrigation) to determination the release of nitrate in water sample. The release of $\mathrm{NO}_{3}^{-}$(Fig. 3) was faster at uncoated urea treated soil than neem coated urea, which ranged from 152 to $22 \mathrm{mg} \mathrm{kg}^{-1}$ for uncoated and ranged from 19 to $24 \mathrm{mg} \mathrm{kg}-1$ at 15 to 105 day for neem coated urea, respectively. The nitrification inhibition $\left(\mathrm{NO}_{3}{ }^{-}\right.$release) was slow in neem cake coated urea as compared to uncoated urea during the trial period. Generally, the release of $\mathrm{NO}_{3}^{-}$has increased rapidly in uncoated urea compared to coated urea which is due to quick nitrification of the released $\mathrm{NH}_{4}{ }^{+}$. Neem cake coated urea decreased the release of nitrate for a long period as a result to nitrification inhibition phenomenon. Due to its slow release property by coated urea with neem cake; it consequently reduces the leaching of nitrogen and then environmental pollution as compared to conventional urea fertilizer. 

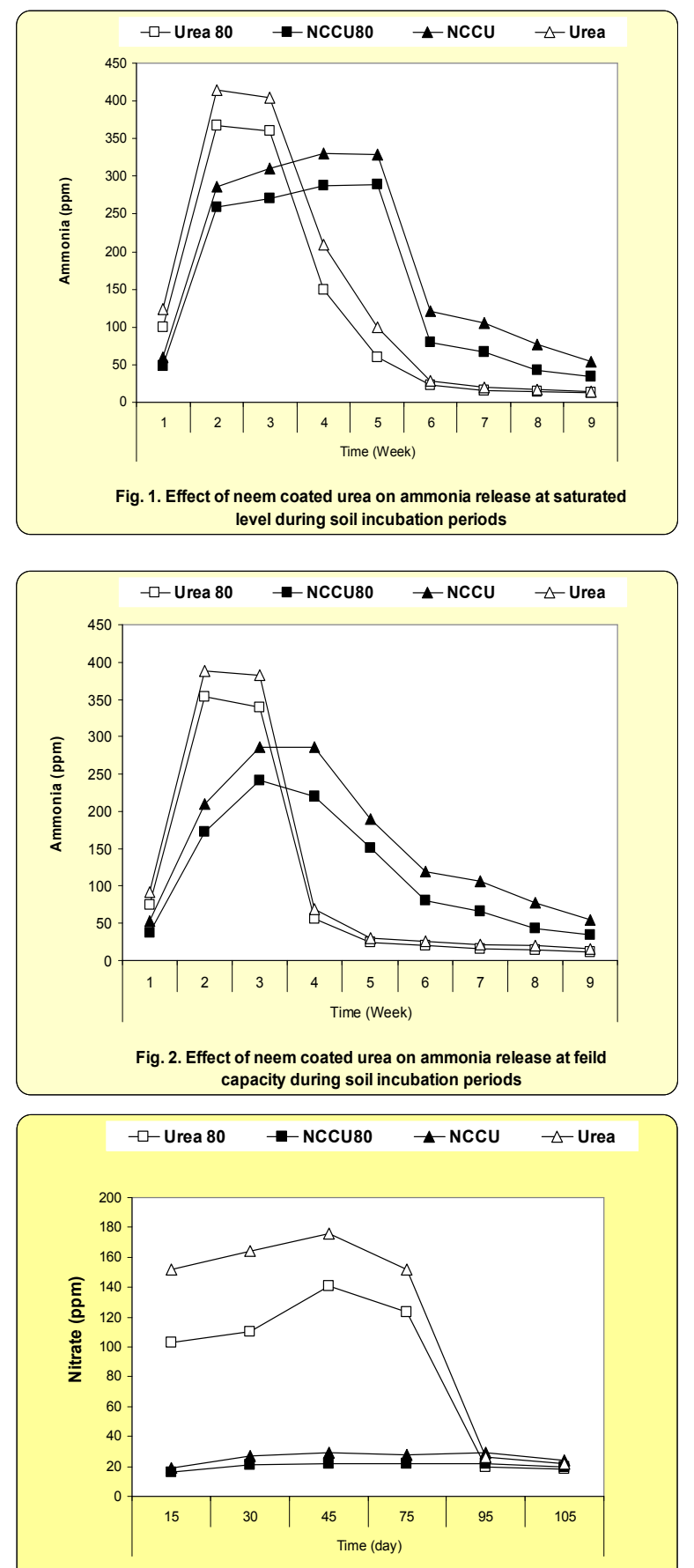

Fig. 3. Effect of neem coated urea on nitrate leaching

The application of neem coated urea fertilizers with or without foliar nano iron led to significantly increase in the grain yield of wheat (Fig. 4) compared to uncoated urea at two rates $(100$ or $80 \%$ from recommended) as a control. It is evident that the yield under different treatments was in the following increasing order: U100+Fe $(10 \%)<$ NCCU100 (18\%) $<$ NCCU100+Fe (24\%) compared to U100 while $\mathrm{U} 80+\mathrm{Fe}(10 \%)<\mathrm{NCCU} 80(19 \%)<\mathrm{NCCU} 80+\mathrm{Fe}$ (26\%) compared to Urea80. Also the results showed a decrease in wheat yield using urea $80 \%$ treatment, this decrease reached to $16 \%$ compared with urea 100 . Also, it was found that NCCU80 and $\mathrm{U} 80+\mathrm{Fe}$ treatments recorded a decrease in yield compared to control 100, but this decrease was observed to be less compared to U80. The decrease percentage in yield reached to $0.4,8$ and $16 \%$ for NCCU80, U80 + Fe and U80 treatments, respectively. This increase in grain yield was due to availability of on nutrient mainly nitrogen by neem coated urea was helped in reducing the leaching and volatilization losses thereby accelerated the availability. It was noted that the addition of iron as foliar spray gave the highest value of yield of wheat plant as compared to without iron as foliar spray. These results may be related to the structure of the ionic compound and the ability of urea to form stable complexes with $\mathrm{Fe}$ and urea through a ligand-exchange reaction (Siam et al., 2006). These results are in harmony with the findings of Gagnon et al., 2012 and Joshi et al., 2014. Zeidan and Nofal (2002) showed that application of micronutrients only $(\mathrm{Fe}, \mathrm{Mn}, \mathrm{Zn}$ and $\mathrm{Cu}$ ) or with adding $1 \%$ urea on growth and yield of wheat caused significant increases in wheat grain protein content, yield and quality of wheat. Results of Seilsepour, 2007 showed that foliar application of $\mathrm{Fe}$ and $\mathrm{Zn}$ increased grain yield and protein content.

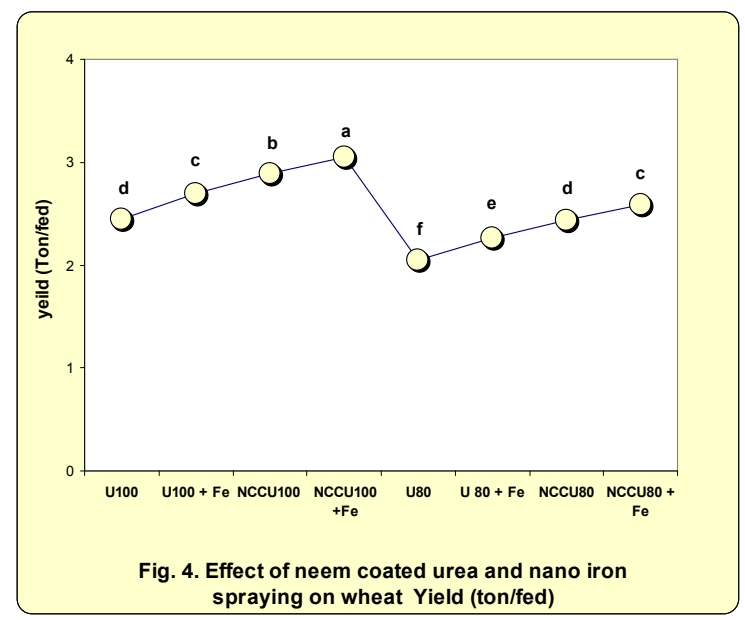

Total Protein and carbohydrate contents of wheat:

Data as shown in Figs 5 and 6 demonstrated that the application of neem coated urea and nano iron foliar application caused significant increments in both of total protein and total carbohydrate values in wheat grain compared to uncoated urea as a control. The highest values of carbohydrates and protein were obtained in NCCU100+Fe. These results related to availability of nitrogen by neem coated urea. These results are in agreement with those of Shilpha et al., (2017). Use of neem urea coating agent helps to retard the activity and growth of the bacteria responsible for denitrification. It prevents the loss of urea in the soil. Neem seed cake performs the dual function of both fertilizer and pesticide, acts as a soil enricher, reduces the growth of soil pest and bacteria, provides macronutrients essential for all plant growth, and helps to increase the yield of plants in the long run, bio degradable and Eco friendly and excellent soil conditioner (Lokanadhan et al., 2012). In this concern, Liu, et al., (2012) reported that application of slow 
release fertilizers increased the percentage of crude protein in grains of maize. Shao et al., (2013) found that application of slow release fertilizers increased the percentage of crude protein in grains of maize.
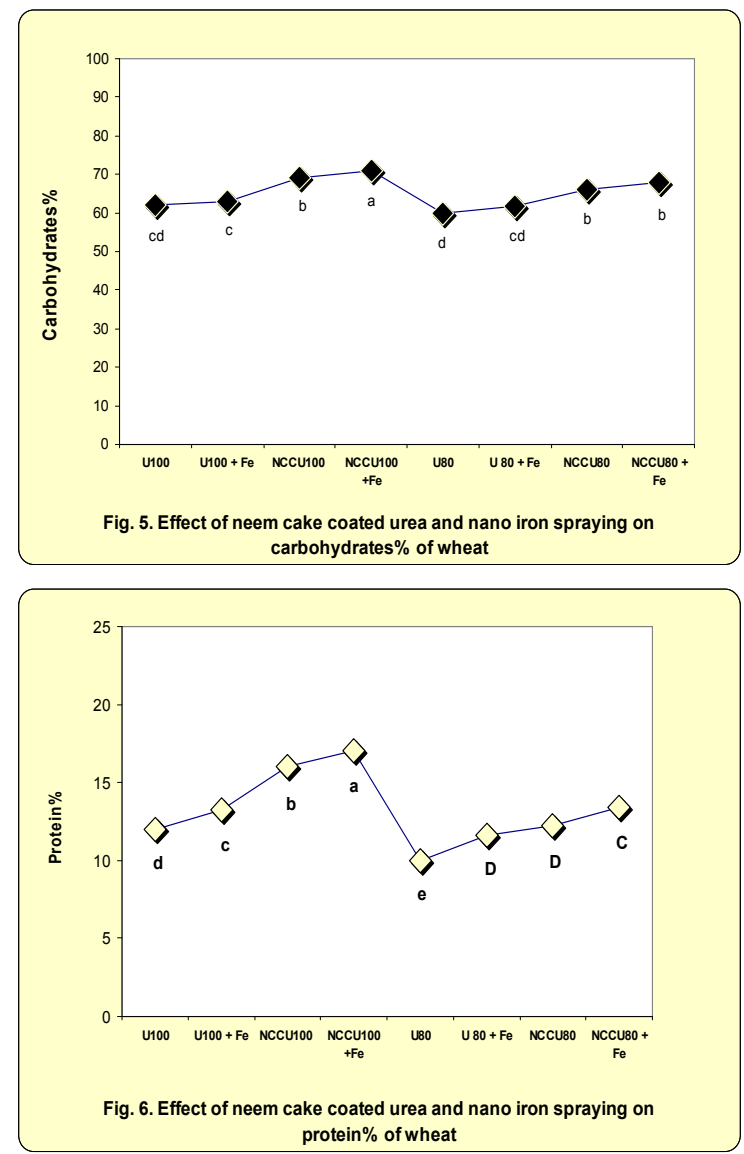

Wheat plant content of macronutrients:

Data in figs. 7, 8, and 9 showed that neem coated urea with or without foliar application of nano $\mathrm{Fe}$ caused significant increments in macronutrients of wheat plant compared to the control values (uncoated urea). The highest values were recorded in NCCU100+Fe followed by NCCU100. This results due to increase availability of macronutrients in soil due to mobilization and release of nutrients from sources. Coating urea with neem cake reduced the leaching and volatilization losses and also inhibits the nitrification process resulting in increased the availability of nutrients in soil and its uptake by plant. These results are in conformity with findings of Sujatha et al., (2007), Singh, (2013) and Sanjaykumar et al., (2015). Pande et al. (1993) observed that the foliar application of $3 \%$ $\mathrm{FeSO}_{4}$ to groundnut increased the uptake of N, K and Fe. Modak and Chavan (1999) reported that application of 20 ppm as $\mathrm{FeSO}_{4}$ with NPK application significantly increased rice grain uptake of N, P, K and Fe over NPK application alone. The application of Fe increased NPK uptake and their concentration in wheat significantly over control (Abbas et al. 2012). Generally, application of the neem coated urea to wheat plants caused an increase in grain yield, crude protein \%, total carbohydrates and macronutrients. It is concluded from these results that controlled released urea fertilizer improved dry matter yield by $14.7 \%$; enhanced $\mathrm{N}$ uptake up to $53.8 \%$ as compared to uncoated urea as control treatment. The results may be due to the useful effect coating material on plant which regulation of nutrient release and increment the nitrogen use efficiency by plant than uncoated fertilizers and decreasing $\mathrm{N}$ leaching losses and provide a constant supply of nutrients to the root.

Nitrogen Uptake and recovery efficiency of wheat yield:

Data in table (2) show the nitrogen uptake and recovery efficiency of wheat plant under different treatments. Urea application at two rates (100 and 80\%) with nano iron foliar treatments increased the nitrogen uptake of wheat by 21.86 and $30.82 \%$ as compared to U 100 and U80, respectively. Data showed that application of neem coated urea (100 and $80 \%)$ without or with nano iron foliar increased nitrogen uptake. This increment reached to $53.84,40.26,77.16,65.26 \%$, respectively. Recovery efficiency of nitrogen increased with foliar spray of nano iron and application of neem coated urea individually or combined at two rates of urea (100 and $80 \%)$. These increases in wheat yield as a result to application of neem coating urea may due to increased $\mathrm{N}$ use efficiency.
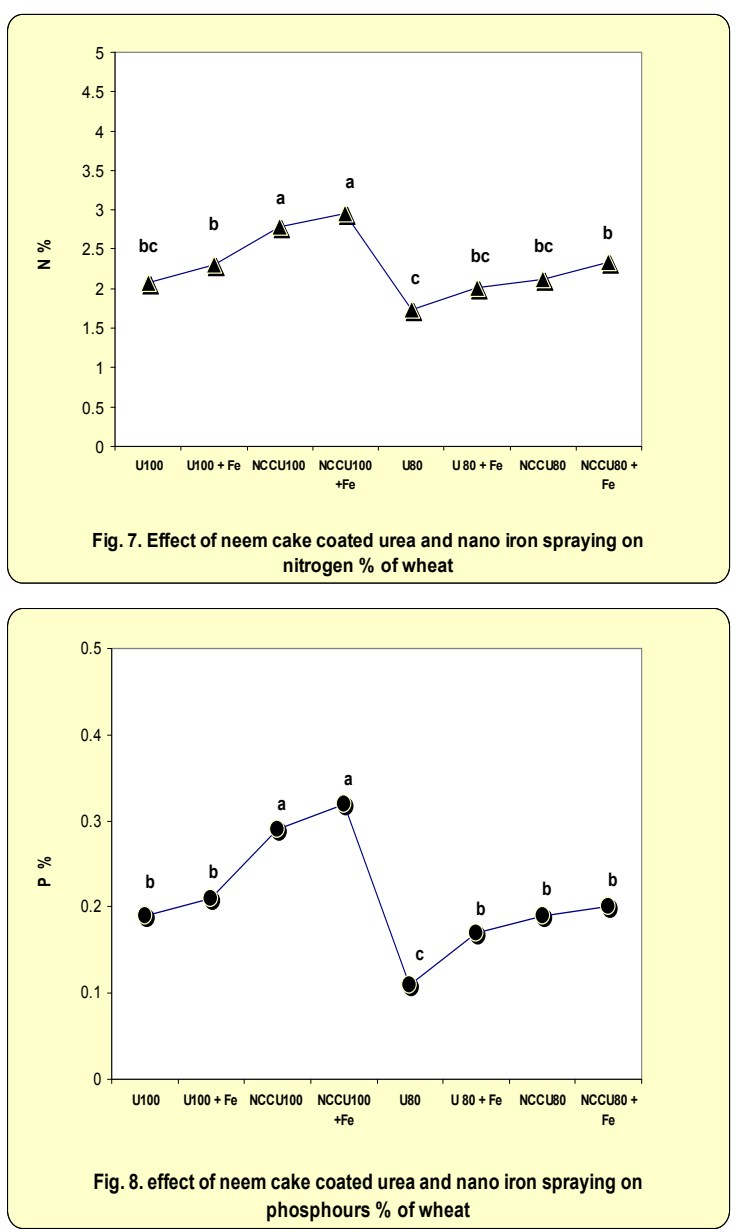


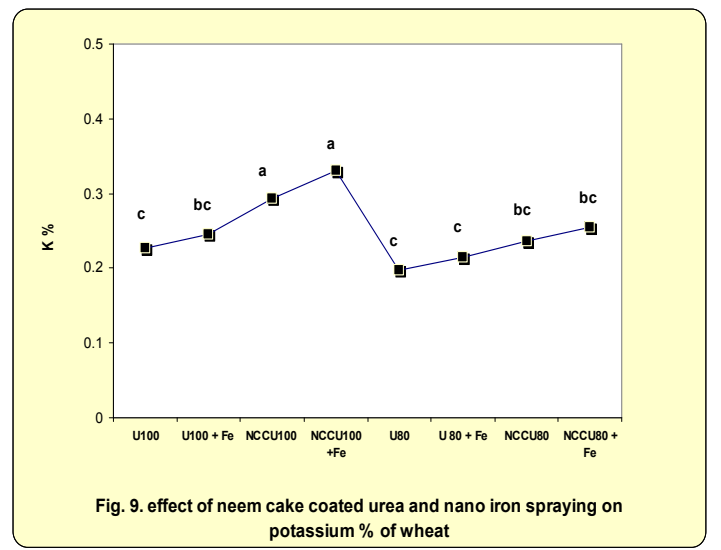

Table 2. Effect of neem coated urea and nano iron foliar on nitrogen uptake and recovery efficiency of wheat yield

\begin{tabular}{lccccc}
\hline Treatment & $\begin{array}{c}\text { yield } \\
\text { (ton/fed) }\end{array}$ & $\begin{array}{c}\text { Nitrogen } \\
\%\end{array}$ & $\begin{array}{c}\text { N- } \\
\text { Uptake } \\
\text { (Kg/fed) }\end{array}$ & $\begin{array}{c}\text { NUE } \\
\%\end{array}$ & $\begin{array}{c}\text { AUE } \\
\text { (Kg/Kg) }\end{array}$ \\
\hline U100 & 2.45 & 2.08 & 50.9 & 4.971 & 31.00 \\
U100 + Fe & 2.70 & 2.3 & 62.1 & 6.085 & 34.33 \\
NCCU100 & 2.81 & 2.79 & 78.3 & 7.715 & 35.80 \\
NCCU100 +Fe & 3.05 & 2.96 & 90.2 & 8.903 & 39.00 \\
U80 & 2.05 & 1.74 & 35.6 & 4.303 & 32.08 \\
U 80 + Fe & 2.31 & 2.02 & 46.6 & 5.677 & 36.42 \\
NCCU80 & 2.36 & 2.12 & 50.0 & 6.098 & 37.25 \\
NCCU80 + Fe & 2.53 & 2.33 & 58.9 & 7.212 & 40.08 \\
\hline NUE
\end{tabular}

NUE\% Nitrogen use efficiency

AUE (Kg/Kg) Agrominic nitrogen efficiency

\section{Economic Evaluation:}

Data of the economical analysis for this study were illustrated in table (3). It is useful to compare total cost of production (TC), total return (TR), and the net return (NR) under the different all treatments. Total return of wheat is based on productivity of wheat grains (Ton/fed). The cost of production included the cost of agricultural practices, tillage, pesticides, fertilizers and materials using for coated urea. It is evident from the results that, generally, all treatments realized reasonable profitability because their investment factor (IF) more than 3 (FAO 2000).

Table 3. Economic evaluation of using of neem coated urea and nano iron foliar

\begin{tabular}{lcccc}
\hline Treatment & $\begin{array}{c}\text { yield } \\
\text { (ton/fed) }\end{array}$ & $\begin{array}{c}\text { Ardab/ } \\
\text { fed }\end{array}$ & $\begin{array}{c}\text { TR } \\
\text { (LE) }\end{array}$ (LE) (LE) & IF \\
\hline U100 & 2.45 & 16.3 & 6860113557256.04 \\
U100+Fe & 2.7 & 18.0 & 7560115564056.55 \\
NCCU100 & 2.81 & 18.7 & 7868122066486.45 \\
NCUC100+Fe & 3.05 & 20.3 & 8540124073006.89 \\
U80 & 2.05 & 13.7 & 5740105046905.47 \\
U80+Fe & 2.31 & 15.4 & 6468107053986.04 \\
NCUC80 & 2.36 & 15.7 & 6608114054685.80 \\
NCUC80+Fe & 2.53 & 16.9 & 7084114859366.17 \\
TR total return, TC total coast, NR net return, IF investment \\
factor
\end{tabular}

The maximum profitable or net return (7300 LE) was obtained from the treatment of NCUC100+Fe followed by the treatment of NCCU100 (6648 LE) then $\mathrm{U} 100+\mathrm{Fe}(6405 \mathrm{LE})$. The data also indicated that the highest investment factor (IF) of 6.89 was recorded with NCUC100+Fe treatment followed by the treatments of $\mathrm{U} 100+$ Fe and NCCU100 which had net return (7300 and $6405 \mathrm{LE}$ ) respectively. These mean that the highest investment factor (IF) does not always give the highest profitable return. Thus it can be concluded that the treatment of NCUC100+Fe achieved the highest income for farmers.

\section{CONCLUSION}

This study recommends by using neem cake used as a natural coated for chemical nitrogen fertilizer to increase the efficiency of $\mathrm{N}$ application and minimize the losses by leaching and to prevent the environmental pollution, as well as the study recommends with foliar application of nano iron to increase wheat yield and reducing the costs of production.

\section{REFERENCES}

Abbas, G.; F. Hussain, Z. Anwar; J.Z.K. Khattak; M. Ishaque; U. Asmat (2012). Effects of iron on the wheat crop (Triticum aestivum L.) by uptake of nitrogen, phosphorus and potassium. Asian, J. Agric. Sci. 4(3): 229-235.

AOAC., (1990). "Official Methods of Analysis". A.O.A.C., Washington, D.C.

Brittenham, G. M. (1994). New Advances in Iron Metabolism, Iron Deficiency and Iron Overload. Current Opinion in Hematology, 1: 549-556.

Chapman, H. and D. Pratt, (1961). Methods of Analysis for Soil, Plant and Water. Dept. of Soil, Plant Nutrition, Univ. of California, U.S.A.

FAO (2000). Fertilizer Demonstrations. A pocket guide for extension officers. Fourth edition. Food and Agriculture Organization of the United Nation. International Fertilizer Industry Association Rome, Italy.

Freed, R.D. and D.E. Scott. (1986). MSTATC. Crop and Soil Sci. Dept.,Michigan State Michigan University, USA.

Gagnon, B.; N. Ziadi, and C. Grant, (2012).Urea fertilizer forms affect grain corn yield and nitrogen use efficiency. Canadian J. Soil Sci., 92: 341-351.

Jackson, M. L. (1973). Soil Chemical Analysis. Pentice Hall of India Pvt. Ltd., New Delhi.

Jarosiewicz, A. and M. Tomaszewska (2003). Controlled-release NPK fertilizer encapsulated by polymeric membranes. J Agric Food Chem., 51(2):413-417.

Joshi, A.; J.K. Gupta, S.K. Choudhary, and D.K. Paliwal, (2014). Efficiency of different nitrogen source, doses and split application on growth and yield of maize (Zea mays L.) in the Malwa region of Madhya Pradesh. IOSR J. Agric. Vet. Sci. 7(2):39-42.

Khalil, S. K.; A. Z. Khan and M. Ramazan (2003). Effect of plant density, nitrogen and zinc on sweet corn. Pak istan J. Sci.,55(3-4):62-66. 
Khalil, I.M.; R. Gutser and U. Schmidhalter (2009). Effects of urease and nitrification inhibitors added to urea on nitrous oxide emission froma loess soil. J. Plant Nutr. Soil Sci.,172: 651-660.

Li, X.; Q. Xu; Y. Su; Q. Yue and B. Gao (2016). Characterization, swelling and slow release properties of a new controlled release fertilizer based on wheat straw cellulose hydrogel. J. Taiwan Inst. Chem. Eng. 60: 564-572.

Liu, C.W., E.H. Zhang, R.Z. Xie, W.R. Liu and S.K. Li, (2012). Effect of different nitrogen supply methods on yield and photosynthesis of maize under the alternative fallow high stubble about narrow row and wide row. Acta Prataculturae Sinica, 21(1): 34-42.

Lokanadhan, S.; P. Muthukrishnan and S. Jeyaraman, (2012). Neem products and their agricultural applications. J. Biopest, 5: 72-76.

Miller, W. L., D. W. King, J. Lin, and D. R. Kester. (1995). Photochemical redox cycling of iron in coastal seawater. Mar. Chem. 50:63-77.

Modak, S.J. and Chavan, K.N. (1999). Response of rice to various levels of $\mathrm{Zn}$ and $\mathrm{Fe}$ with and without FYM in black calcareous soil. Madras Agric. J. 86(4-6): 206-209.

Murphy, R. P. (1958). Extraction of plant samples and the determination of total soluble carbohydrates. J. Sci. Food Agric. 9: 714-717.

Page, A. L.; R.H. Miller; and D.R. Keeney (1982). Methods of Soil Analysis. II: Chemical and Microbiological Properties, 2nd ed.Am. Soc. Agron .Inc; Soil. Soil Sci Soc. Am. Inc, Madison, Wisconsin U.S.A.

Pande P.K.; H.W. Ravankar; G.S. Laharia; R.P. Ganwande and V.R. Padole (1993). Effect of iron on yield and uptake of nutrients in groundnut. PKV Res. J. 17:135-137.

Purkayastha, T.J.; J.C. Katyal and N.N. Goswami (1997) Evaluation of ammonia volatilization from some modified urea fertilizers. Indian Soc. Soil Sci. 45:9-14.

Ramesh, K.A.K. Biswas; J. Somasundaram and A. Subbarao (2010). Nanoporous zeolites in farming: Current status and issues ahead. Curr. Sci. 99:760-764.

Sanjaykumar, V.V., T.S. Vageesh; G.J. Abhiram and P. Shilphashree (2015). Effect of NPK fertilizers and neem oil coated urea on productivity and nutrient use efficiency in maize. Karnataka $\mathrm{J}$. Agric. Sci., 28(2): 185-188.

Schmutterer, H. (2002) The Neem Tree: Source of Unique Natural Products for Integrated Pest Management, Medicine, Industry And Other Purposes (Hardcover), 2nd Edition, Weinheim,Germany: VCH Verlagsgesellschaft. ISBN 3-527-30054-6

Seilsepour, M. (2007). The study of Fe and Zn effects on quantitative and qualitative parameters of winter wheat and determination of critical levels of these elements in Varamin plain soils. Iranian J. Pajouhesh \& Sazandegi, 76 in Agron. Horticult., 20(3): 123-133.
Shao, G.Q.; J. Li, T.Y. Ning and Y.H. Zheng, (2013). Responses of photosynthesis, chlorophyll fluorescence, and grain yield of maize to controlled-release urea and irrigation after anthesis. J. of Plant Nut. and Soil Sci., 176(4): 595-602

Shilpha, S. M.; T. M. Soumya; G. K. Girijesh and B. C. Dhananjaya ( 2017). Effect of Different Natural Oil Coated Urea Fertilizers on Productivity and Nutrient Uptake of Maize. Int. J. Pure App. Biosci. 5 (2): 807-812.

Siam, H. S.; K.h.S. Moursy and H.I. El-Aila, (2006). Effect of different sources and methods of application of iron on the improvement of growth and nutrient uptake by Sudan grass. Egypt. J. Appl. Sci., 21(IIB): 772-789.

Singh, A.L. and D. Dayal (1992). Foliar application of iron for recovering groundnut plants from limeinduced iron deficiencies chlorosis and accompanying losses in yields. J. Plant Nut., 15:1421-1433.

Singh K., A. Singh and D. K. Singh (1996). Molluscicidal activity of neem (Azadi-rachta indica). J. Ethnopharmacol, 52: 35-40.

Singh, V. (2013). Effect of different organic manures and fertilizers on yield and nutrient uptake of maize. MS (Agri.) Thesis, UAS, Bangalore.

Smith, D.; G.M. Paulsen and C.A. Raguse (1964). Extraction of total available carbohydrates from grass and legume tissue. Plant Physiol. 39: $960-$ 962.

Sujatha, M.G.; Y.B. Lingaraju; B.Y. Palled and K.V. Ashalatha, (2007). Importance of integrated nutrient management practice in maize under rainfed condition. Karnataka J. Agric. Sci., 21(3): 334-338.

Sun, Y.-P., X.Q. Li; J. Cao; W.X. Zhang and H. P. Wang (2006). Characterization of zero-valent iron nanoparticles. Advances in Colloid and Interface Sci., 120: 47-56.

Susherman and Anggoro (2011). Producing slow release urea by coating with Starch/Acrylic acid in Fluid Bed Spraying. IJET-IJENS 11(6): 77-80.

Tomaszewska M; A. Jarosiewicz and K. Karakulski (2002). Physical and chemical characteristics of polymer coatings in CRF formulation. Desalination., 146: 319-323.

Tyliszczak, B. J. Polaczek; J. Pielichowski and Pielichowski K. (2009). Preparation and Properties of Biodegradable Slow- Release PAA Superabsorbent Matrixes for Phosphorus Fertilizers. Macromol. Symp., 279: 236-242

Zareie S., P. Golkar and G.H. Mohammadi. (2011). Effect of nitrogen and iron fertilizers on seed yield and yield components of safflower genotypes. African Journal of Agricultural Research. 6(16): 3924-3929.

Zeidan M.S and O.A. Nofal (2002). Effect of urea on the efficiency of spraying iron, manganese, zinc and copper on wheat. Egypt, J. Agron. 24: 121131. 
Zhang, X.L.; Z. Bing; Z. Xing (2003). Research and control of well water pollution in high oesophageal cancer areas, World J. Gastroenterol, 9 (6): 1187-1190.

Zhang, A.F.; L.Q. Cui; G.X. Pan; L.Q. Li; Q. Hussain and X. Zhang. (2010). Effect of Biochar Amendment on Yield and Methane and Nitrous Oxide Emissions from a Rice Paddy from Tai Lake Plain, China. Agriculture, Ecosystems and Environment, 139: 469-475.
Zou, H. T.; Y. S. Wang, H. W. Song (2009). The production of organic-inorganic compound filmcoated urea and the characteristics of its nutrient release," Agricultural Sciences in China, vol. 8 (6): 703-708.

\section{التأثير البيئي لتطبيقات اليوريا المغلفة بالنيم والرش بالحديد النانوعلى ترشيد الأسمدة النيتروجينية الكيماوية ومحصول القمح

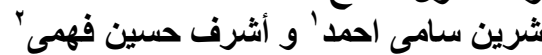

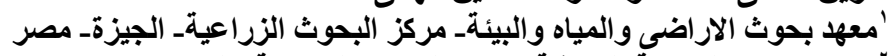

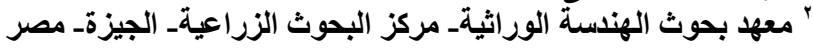

أصبح استخدام الأسمدة بطيئة اللتحلل اتجاه جديد لترشيد استهلاك الأسمدة والتقليل من التلوث البيئي. تهدف هذه الدراسة

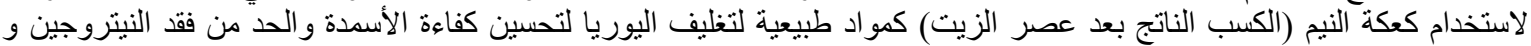

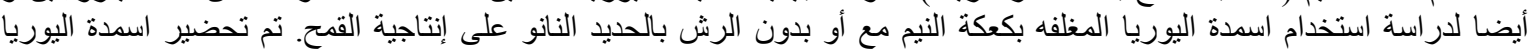

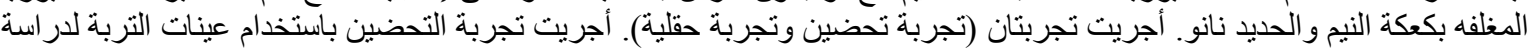

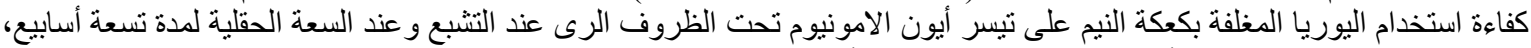

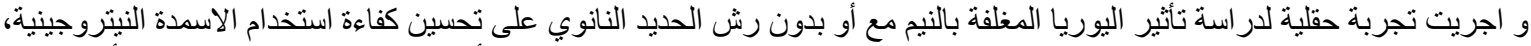

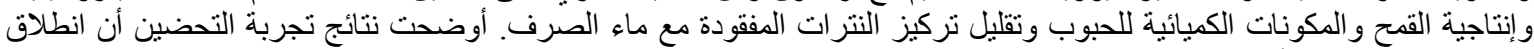

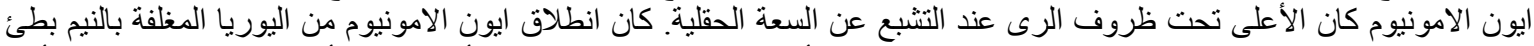

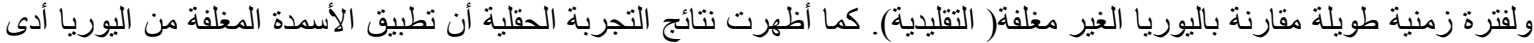

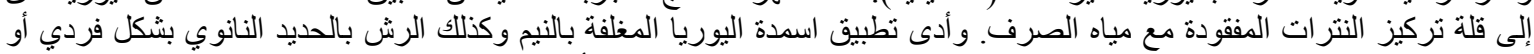

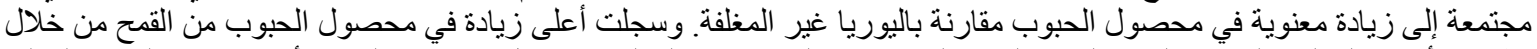

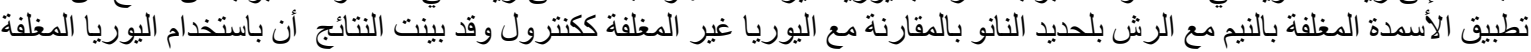

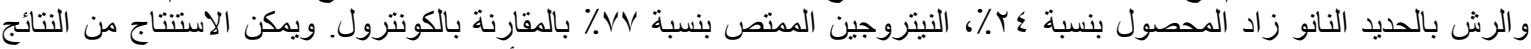

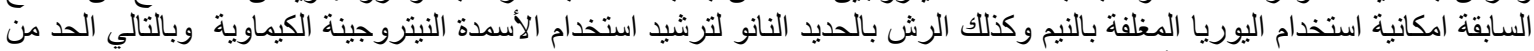

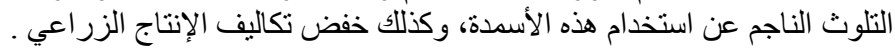

